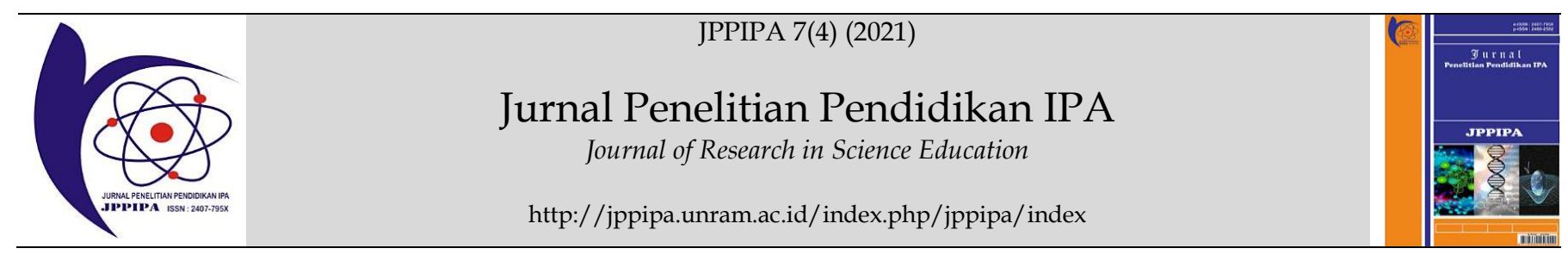

\title{
Application of Project-Based Learning Through a STEM Approach to Improve Learning Outcomes During a Pandemic
}

\author{
Yoana Nurul Asri ${ }^{*}$, Desta Sulaesih Mursyidah2, Vini Rizqi ${ }^{3}$ \\ ${ }^{1}$ Avionica, Faculty of Engineering, Nurtanio University, Bandung, Indonesia \\ 2 Management, Faculty of Economics, Nurtanio University, Bandung, Indonesia \\ ${ }^{3}$ Accounting, Faculty of Economics, Nurtanio University, Bandung, Indonesia
}

\section{DOI: $10.29303 /$ ippipa.v7i4.819}

\section{Article Info}

Received: June $28^{\text {th }}, 2021$

Revised: September $14^{\text {th }}, 2021$

Accepted: October 14th 2021

\begin{abstract}
Research has been conducted on applying project-based learning (PjBL) through the Science, Technology, Engineering, and Mathematics (STEM) approach during the pandemic. Tests were given to 30 first-year students conducted by Distance Learning (DL). The research method used a pre-post experimental one-group design. The results showed a minimum pretest score of 50 and a maximum value of 70 . After being treated, the minimum posttest result was 75 , and the maximum result was 90 . There was a significant difference of 60 for the average pretest and posttest from the average pretest and posttest. The average posttest is 79 .
\end{abstract}

Keywords: PjBL; Pandemic; STEM; Distance Learning (DL)

Citation: Asri, Y., Mursyidah, D., \& Rizqi, V. (2021). Application of Project-Based Learning Through a STEM Approach to Improve Learning Outcomes During a Pandemic. Jurnal Penelitian Pendidikan IPA, 7(4), 719-722. doi:https://doi.org/10.29303/jppipa.v7i4.819

\section{Introduction}

The emergence of the Covid-19 outbreak has provided policies in all aspects of life, one of which is education which requires all activities to be carried out at home (Kusumadewi et al., 2020), including teaching and learning activities that are required online. Although everything has been done to overcome this new adaptation of teaching and learning activities, obstacles are still found during the process, starting limited skills in using technology to a lack of understanding in learning (Jaenudin, 2021). Therefore, even though online learning is carried out, teaching and learning activities must remain interesting that carries a student center with a series of activities in constructing knowledge, one of which is project-based learning (Arizona et al., 2020) so that it can provide satisfactory results.

Project-based learning, known as Project-Based Learning (PjBL), actively involves students transferring knowledge and skills packaged in a real problem that occurs around the environment (Mahendra, 2017). The
$\mathrm{PjBL}$ uses a series of questions that will be answered through findings during the learning process. Not only that, various skills are trained during learning ranging from building concepts, hands-on skills, creativity, and group collaboration.

Through PjBL learning, students are required to carry out an in-depth investigation of the main discussion topic. Students will be trained in psychomotor abilities (Fajarwati et al., 2017) (Sutrisno et al., 2019), learn to explore, and construct knowledge that has been built with new knowledge found on real and relevant problems during the learning process (Eliza et al., 2019). The end result is the product of applying skills, analyzing, designing, creating, and presenting products based on real experiences. In addition, the implementation of PjBL during the pandemic is considered quite effective in improving the quality of learning and student creativity (Karnando et al., 2021).

Apart from $\mathrm{PjBL}$, hands-on skills still have to train other fundamental skills, especially the needs during the industrial revolution 4.0 (Mubarok et al., 
2020). One of them is the STEM approach through four main fields: Science, Technology, Engineering, and Mathematics (STEM). It is proven that STEM can improve skills and interactions between teachers and students (Oktaviani et al., 2021) (Asri, 2018).

So that, through PjBL-based learning integrated with the STEM approach, can maximize understanding of concepts (Jauhariyyah et al., 2017), especially improving learning outcomes. Not only that, creativity and critical thinking skills can be trained through the four areas of the STEM approach (Hilmi et al., 2020). Through STEM, engineering education can be of higher quality because the motivation to learn science and mathematics will be honed and hands-on skills from the fields of engineering and technology.

\section{Method}

This research was conducted at the University of Nurtanio Bandung in the 2020/2021 electrical Basics course. The method used is a pre-post experimental design with one group pretest-posttest, which examines the effect of project-based learning with a STEM approach in improving learning outcomes through e-study. The subjects studied were 30 students.

The research was conducted through three stages, namely preparation, implementation, and testing. At the implementation stage, observations were made to collect information on the implementation of learning. The observation sheet was designed in the STEM aspect. Learning outcomes were obtained from the pretest and posttest questions as many as 20 items.

In this study, students were given a project task: making a model of a house equipped with electrical installations in groups. Students are given one week to complete a house plan and determine what components are needed. Components are prioritized to take advantage of whatever is in the environment without having to buy new ones. Then the results of the work are presented. Furthermore, the group was given two weeks to complete the house mockup based on the floor plan previously made, and then the electrical installation was installed as well as the trial phase, and students were instructed to calculate the amount of electrical power needed. In the last stage, the results of this work are presented and responded to by other groups to provide opportunities so that they can correct each other.

\section{Result and Discussion}

During the research process in the application of project-based learning with the STEM approach, students looked enthusiastic and active in every stage, especially in designing the floor plan and determining the desired electrical installation. There are no significant obstacles during this process. It can be seen in Figure 1 and Figure 2 that each group discussed with each other to determine the best design based on their version. Figure 2 shows one of the designs that have been presented.

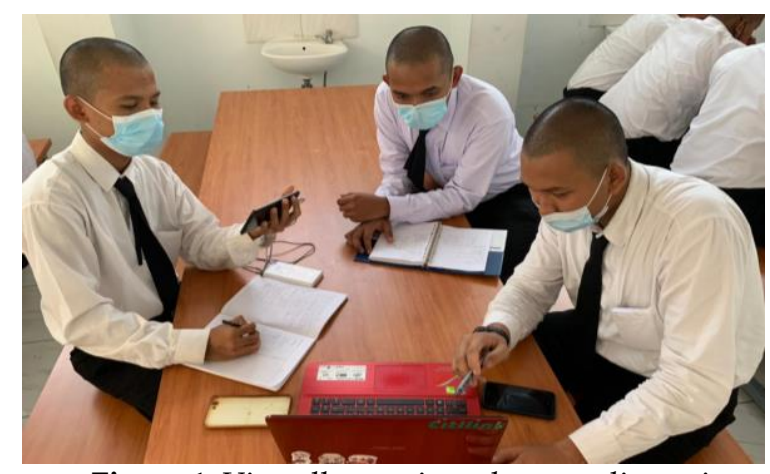

Figure 1. Virtually monitored group discussion Activities

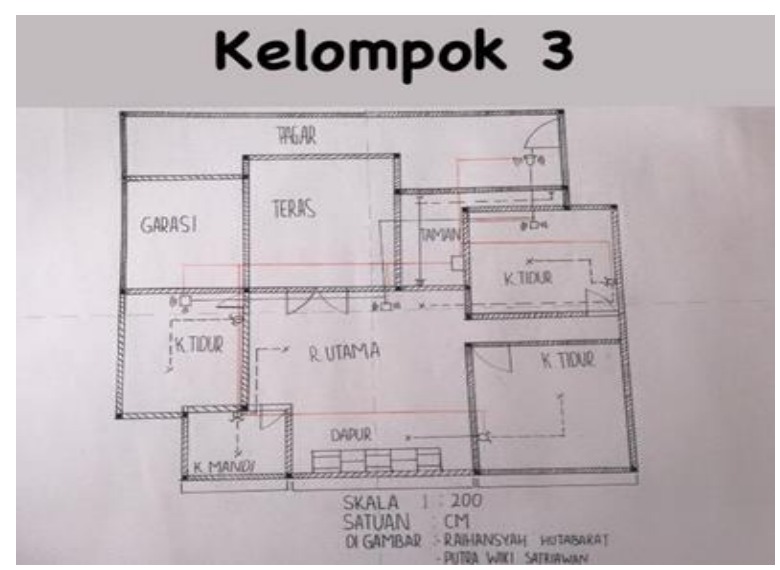

Figure 2. One of the plans done by the group

After each group has finished presenting and accompanied by responses from other groups regarding the input of ideas, and then the next step is to install every component needed until the project can work as it should. In Figure 3, one group presents the installation of cables and other electrical components.

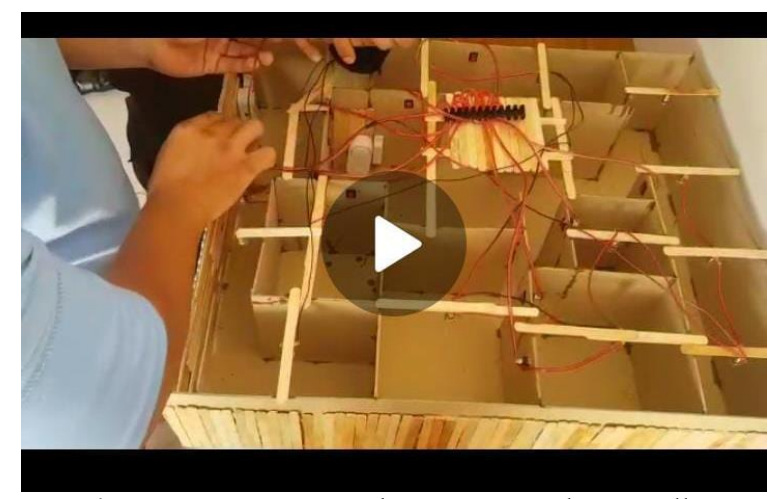

Figure 3. Group members present the installation of electrical installations 
Students are given time to complete the circuit. In this stage, two groups were found who were still having difficulties because their project did not work due to an electrical short circuit. In this stage, each group is trained in critical and creative thinking skills. As stated by Sumarni that Ethno-STEM can improve critical and creative thinking skills (Sumarni \& Kadarwati, 2020). So that, it is proven, there is no need to wait a long time to be able to return it to a normal state again because each member tries to find solutions to the problems found through literacy (Eliana et al., 2015). This is in line with research conducted by Insyasiska in his journal (Insyasiska et al., 2017).

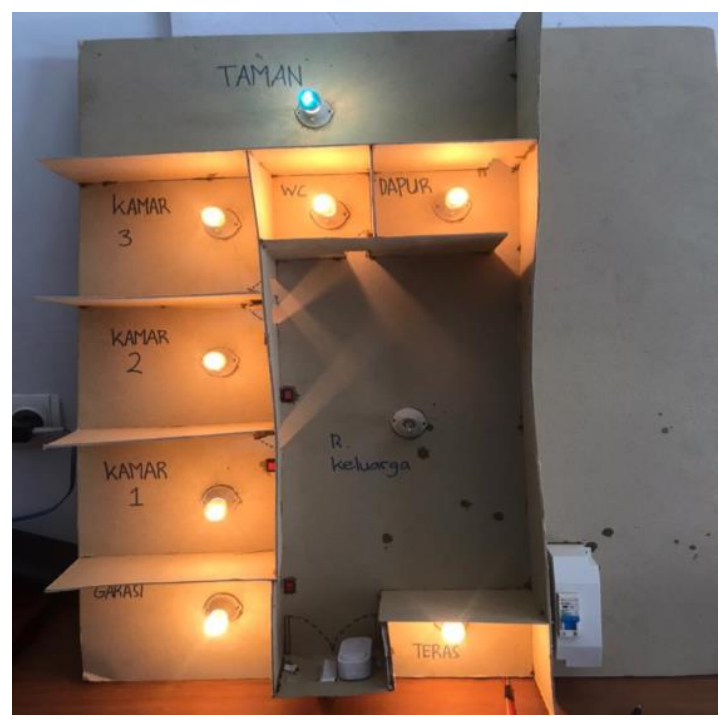

Figure 4. Product results from one group

In Figure 4. The product results from one of the groups are shown, then the electrical quantities are calculated, namely the amount of electric current flowing in the circuit, electrical resistance, voltage, and electric power obtained as in table 1 . The stages in science are obtained from the concepts they relate between previous knowledge and knowledge acquired during the working process. The technology stage is developed in the design stage and the use of information technology, the engineering stage is trained while they are working on a project from a series of electrical installation processes, and the final stage, namely mathematics, is trained when they calculate electrical quantities. The integration of project-based learning with STEM is proven to improve learning outcomes as shown in Table 1.

Table 1. Learning Outcomes on Electrical Materials

\begin{tabular}{llll}
\hline No & Learning Outcomes & $\begin{array}{l}\text { Pretest } \\
\text { scores }\end{array}$ & $\begin{array}{l}\text { Posttest } \\
\text { scores }\end{array}$ \\
\hline 1 & Minimum Value & 50 & 70 \\
2 & Maksimum Value & 75 & 90 \\
3 & Average Value & 60 & 79 \\
\hline
\end{tabular}

The minimum pretest results obtained are 50, and the maximum value is 70 . While the posttest results given after the integration learning process between PjBL and STEM get a minimum score of 75 and a maximum of 90 . The average score is 60 for the pretest and 79 for the posttest. From the results obtained from the pretest and posttest above, it can be concluded that there is a significant increase between before STEM learning and after STEM learning.

\section{Conclusion}

From the research result, it can be concluded that there were no significant obstacles during the learning process, either from $\mathrm{PjBL}$ or from the fourth stage of the STEM field. Likewise, an increase in pretest and posttest learning outcomes was obtained before PjBL learning with the STEM approach was carried out compared to after PjBL learning with the STEM approach with an average score for pretest of 60 and posttest of 79. These results are comparable to previous research (Mutakinati et al., 2018) that STEM and PjBL will positively impact student learning outcomes.

\section{References}

Arizona, K., Abidin, Z., \& Rumansyah. (2020). Pembelajaran Online Berbasis Proyek Salah Satu Solusi Kegiatan Belajar Mengajar Di Tengah Pandemi Covid-19. Jurnal Ilmiah Profesi Pendidikan. doi: https://doi.org/10.29303/jipp.v5i1.111 [Indonesian]

Asri, Y. N. (2018). Pembelajaran Berbasis STEM Melalui Pelatihan Robotika. WaPFi (Wahana Pendidikan Fisika), 3(2), $74 . \quad$ doi: https://doi.org/10.17509/wapfi.v3i2.13735 [Indonesian]

Eliana, E., Senam, S., Wilujeng, I., \& Jumadi, J. (2016). The Effectiveness Of Project-Based E-Learning To Improve ICT Literacy. Jurnal Pendidikan IPA Indonesia, 5(1), 51-55. doi:https://doi.org/10.15294/jpii.v5i1.5789.

Eliza, F., Suriyadi, S., \& Yanto, D. (2019). Peningkatan Kompetensi Psikomotor Siswa Melalui Model Pembelajaran Project Based Learning (PjBL) di SMKN 5 Padang. INVOTEK: Jurnal Inovasi Vokasional Dan Teknologi, 19(2), 57-66. https://doi.org/https://doi.org/10.24036/invot ek.v19i2.427 [Indonesian]

Fajarwati, S. K., Susilo, H., \& Indriwati, S. E. (2017). Pengaruh Project Based Learning Berbantuan Multimedia Terhadap Keterampilan Memecahkan Masalah Dan Hasil Belajar Psikomotor Siswa Kelas XI SMA. Jurnal 
Pendidikan: Teori, Penelitian, \& Pengembangan Journal of Education, 2.(3). doi: http://dx.doi.org/10.17977/jptpp.v2i3.8583

[Indonesian]

Hilmi, S., Suwarma, I. R., Kaniawati, I., \& Suhendi, E. (2020). Analisis Pengaruh Pembelajaran Fisika Berbasis STEM terhadap Keterampilan Creative Problem Solving Siswa. Seminar Nasional Fisika. 1(1). Retrieved from: http:// proceedings.upi.edu/index.php/sinafi/a rticle/view/1252 [Indonesian]

Insyasiska, D., Zubaidah, S., \& Susilo, H. (2017). Pengaruh Project Based Learning Terhadap Motivasi Belajar, Kreativitas, Kemampuan Berpikir Kritis, Dan Kemampuan Kognitif Siswa Pada Pembelajaran Biologi. Jurnal Pendidikan Biologi, 7(1), 9-21. doi:http://dx.doi.org/10.17977/um052v7i1p921. [Indonesian]

Jaenudin, A. (2021). Digital Literation as A Teacher Solution in Learning The Digital Era and Pandemic Covid-19. Economic Education Analysis Journal, 10(1), 1-11. https://doi.org/10.15294/eeaj.v10i1.44566.

Jauhariyyah, F. R., Suwono, H., \& Ibrohim. (2017). Science, Technology, Engineering and Mathematics Project Based Learning (STEMPjBL) Pada Pembelajaran Sains. Seminar Nasional Pendidikan IPA. Retrieved from: http://pasca.um.ac.id/conferences/index.php/i pa2017/article/view/1099 [Indonesian]

Karnando, J., Rezki, I., \& Tasrif, E. (2021). Efektivitas EModul Berbasis Project Based Learning Selama Pembelajaran Jarak Jauh. JAVIT : Jurnal Vokasi Informatika, 1(1), 1-4. doi: https://doi.org/10.24036/javit.v1i1.17.

[Indonesian]

Kusumadewi, R., Yustiana, S., \& Nasihah, K. (2020). Menumbuhkan Kemandirian Siswa Selama Pembelajaran Daring Sebagai Dampak Covid-19 Di SD. Jurnal Riset Pendidikan Dasar, 1(1). doi: https://doi.org/10.30595/.v1i1.7927 [Indonesian]

Mahendra, I. (2017). Project Based Learning Bermuatan Etnomatematika Dalam Pembelajar Matematika. JPI (Jurnal Pendidikan Indonesia), 6(1), 106-114. doi:http://dx.doi.org/10.23887/jpiundiksha.v6i1.9257. [Indonesian]

Mubarok, I., Nana, N., \& Sulistyaningsih, D. (2020). Analisis Penerapan Model Pembelajaran POE2WE Berbasis Hands On Activity Terhadap Kemampuan Berpikir Kritis Siswa. Edufisika: Jurnal Pendidikan Fisika, 2(5). doi: https://doi.org/10.22437/edufisika.v5i02.10804 [Indonesian]
Mutakinati, L., Anwari, I., \& Kumano, Y. (2018). Analysis of Studentsâ€TM Critical Thinking Skill of Middle School through STEM Education Project-Based Learning. Jurnal Pendidikan IPA Indonesia, 7(1), 54-65. doi:https://doi.org/10.15294/ipii.v7i1.10495

Oktaviani, I., Rini, I. A., Ulfah, M., \& Andriana, A. (2021). Pengenalan Pembelajaran daring Berbasis STEM Untuk Guru IPA di SMA 9 Bandar Lampung. Jubaedah: Jurnal Pengabdian Dan Edukasi Sekolah, 1(1). doi: https://doi.org/10.46306/jub.v1i1 [Indonesian]

Sumarni, W., \& Kadarwati, S. (2020). Ethno-Stem Project-Based Learning: Its Impact to Critical and Creative Thinking Skills. Jurnal Pendidikan IPA Indonesia, 9(1), $11-21$. doi:https://doi.org/10.15294/jpii.v9i1.21754.

Sutrisno, A., Mila, H., \& Santoso, S. (2019). Perbedaan Kemampuan Kognitif Siswa dengan Menggunakan Model Problem Based Learning (PBL), Project Based Learning (PjBL) dan Inkuiri Di SMP Negeri 24 Bengkulu Utara. Seminar Nasional Sains \& Entrepreneurship, 1(1). Retrieved from:

http://conference.upgris.ac.id/index.php/snse/ article/view/195 [Indonesian] 